\title{
Analysis of Inequality in Economic Development District / City in North Sumatra
}

\author{
Linda Septi Yanti Sianipar ${ }^{1 *}$, Rahmad Sembiring ${ }^{2}$, Annisa Ilmi Faried ${ }^{3}$, \\ ${ }^{1,2,3}$ Universitas Sumatera Utara, Indonesia \\ *linda_sianipar@yahoo.com
}

\begin{abstract}
Development planning in Indonesia is directed to create a society that is more prosperous, prosperous and equitable. Policy development is implemented to achieve high economic growth potential and by utilizing existing resources. But the fruits of development have not been felt evenly and sometimes there are regional disparities. This study aims to identify and analyze the influence of PDB, population, development expenditure and unemployment rate on the imbalance of economic development between districts / cities in North Sumatra. The data used is panel data from the year 2011 - 2018 on 25 districts / cities in the province of North Sumatra. Sources of data from the Central Statistics Agency of North Sumatra Province with method Fixed Effect, with testing conducted by classical assumption test and statistical tests. With the help of Eviews 6.0 program data processing, data analysis results showed that the PDB variable is negative and significant effect at $\alpha=10 \%$, variables of population and development expenditure has positive and significant at $\alpha=10 \%$, while the unemployment rate did not significantly influence the disparity of economic development in North Sumatra. Regression results on the model is R-Squared $=0.994995$, which means that the independent variables affect the dependent variable was $99.49 \%$ and the remaining $0.52 \%$ is influenced other variables outside the model are analyzed.
\end{abstract}

Keywords: Disparities, GDP, Population, Development Spending, Unemployment Rate

\section{Introduction}

National development in an area is focused on economic development through efforts to economic growth. Where the goal of economic development creates growth and changes in economic structure, social change, reducing or eliminating poverty, reducing disparity (disparity), and unemployment [1]. The main cause of inequality is differences in socioeconomic structure and other factors.

Development planning in North Sumatra is directed towards realizing a more prosperous, prosperous and just society in accordance with Nawacita item 3 to develop Indonesia from the periphery by strengthening regions and villages within the framework of a unitary State. Policies development is carried out to achieve high economic growth by means of utilize the potential and available resources. But the results of development are sometimes not felt evenly and there are still gaps between regions.

Regional development can enable the region to manage its economic resources to be useful and successful for the advancement of the region and the welfare of the community. To 
advance Regional development the most important concerns the process of growth and equitable development. Promoting the regional economy is the main objective of the implementation of Regional Autonomy. The policy of providing regional autonomy is a strategic step. First, regional autonomy and decentralization are answers to local problems in the form of the threat of national disintegration, poverty, inequality of development, low quality of life of the people, and problems of human resource development. Second, regional autonomy and decentralization are regional strategic steps to welcome the era of economic globalization by strengthening the regional economic base. This is very important for the Regional Government in determining the efforts that can be made to encourage economic growth in the region [2]. One way to assess the achievement of economic growth is through the calculation of Gross Domestic Product (PDB) according to prices valid in the base year. The value obtained is called PDB according to a fixed price that is the price in force in effect in the base year. At the regional level it is called Gross Regional Domestic Product (PDRB). This is enough to prove that the regional autonomy imposed by North Sumatra has positive results because it can increase the economic growth of North Sumatra from year to year and of course this will impact on other sectors and it is hoped that conditions like this will continue in the long term. Long and followed by other developments that will further improve the economic and political situation.

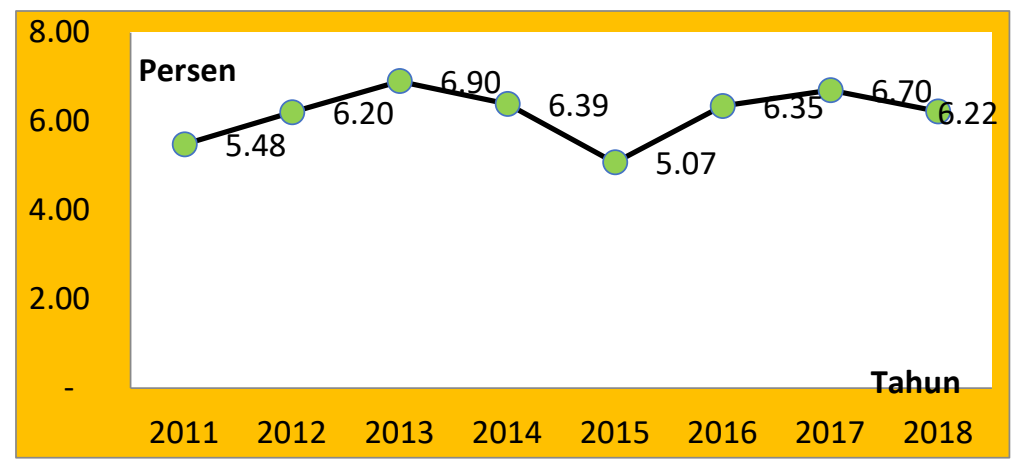

Sumber : BPS, Sumatera Utara Dalam Angka Tahun 2018

Fig 1. Economic Growth Based on 2000 Constant Prices 2011 - 2018.

From Figure 1, it explains the economic growth during 2011 to 2018 although it fluctuates but shows a positive direction. Recorded economic growth in 2011 of 5.48 percent to 6.90 percent in 2012. But in 2012 economic growth had dropped to the level of 6.39 percent to the level of 5.07 percent in 2015 . The economy rose again in 2016 it reached 6.35 percent until 2018 economic growth reached 6.22 percent.

Generally economic growth is often used as a measure for the success of economic development and is often interpreted as a series of businesses in an economy to develop its economic activities so that more infrastructure is available, more and more companies are growing, higher levels of education, technology is increasing. Regional economic development also requires cooperation between the government, private sector and the community in managing the resources owned by the region in order to increase economic growth and employment as much as possible. Indicators of development success are shown by economic growth and reduced inequality both in the distribution of population income and 
between regions. Inequality of development in principle is an economic inequality that implies poverty and inequality.

The approach in conducting this research using the Williamson Index approach with the reason this index is quite able to explain the extent of inequality that occurs between regions, it is quite easy to interpret the number of inequality obtained, practical and quite commonly used in measuring inter-regional development inequality. If the index is smaller, the regional inequality is also smaller and vice versa, if the index is greater, the greater inequality between regions will occur.

The Williamson Index calculation uses PDRB per capita in relation to population per region. Basically the Williamson Index is the coefficient of variation of the average distribution value calculated based on estimates of the values of PDRB and population in districts / cities in North Sumatra.

\section{Formulation of the problem}

Based on the description above, the formulation of the problem that can be taken as a basis in this study is, "How does the effect of PDRB, population, development spending and unemployment rate on inequality of economic development between districts / cities in North Sumatra"

\section{Research purposes}

The purpose of this paper is to determine and analyze the effect of PDRB, population, development expenditure and unemployment rate on economic development disparities between districts / cities in North Sumatra.

\section{Benefits of research}

The expected benefits of this research are:

1) Adding, completing as well as comparing existing research results concerning the same topic.

2) As information and reference material for further studies on the same topic.

3) It is expected that the results of this study can be a contribution of thought for students of the faculty of economics, especially students with Development Economics study programs.

4) As an additional insight for the authors to find out how the imbalance of economic development between districts / cities in North Sumatra.

\section{Framework}

Basically, development is a change in variables such as population, PDRB, per capita income, development expenditure, investment, and labor and so on for a certain period of time in an area that is clearly limited. But in the process of economic development the problem of accelerating economic growth between regions is different, resulting in regional inequalities that cannot be avoided given the differences in the wealth of different resources between regions and the basis for the implementation of development itself and different concentrations. Based on the causes of regional inequality and the level of disparity in income between regions, it tends to widen from year to year so a research framework can be drawn that is income inequality that is affected by PDRB, population, government development expenditure and labor force.

PDRB is a measure for economic development can negatively affect the income inequality of districts / cities in North Sumatra. This means that with an increase in PDRB will lead to economic activity and increased prosperity of the population so that income inequality in the district of the city will decrease. Large population and continues to increase will be a 
burden on the economy, especially areas that have large populations but are relatively small in absorbing labor. This will be a problem of inequality between residents who have significant income differences.

Development that uses large and directed funds will be maximized in implementing equitable development and reduce gaps or disparities between residents and between regions. A more efficient, effective and equitable government development expenditure will have an impact on the level of the gap itself. The number of workforce that exists can affect the level of inequality, with an increase in the workforce means there is an increase in economic activity and the level of prosperity, so that inequality has decreased. The number of the workforce has a negative influence on income inequality between districts / cities. It means that increasing labor force will reduce disparity in income between districts / cities in North Sumatra Province. Opening new jobs will certainly absorb new workers so that the number of the workforce has increased. With the increase in the number of this workforce will increase people's income which in turn will increase people's purchasing power so that demand for goods and services is greater which then encourages producers to produce more and so on, thus economic activity will run well and economic disparity will decrease.

Based on the description of the framework of thought, the relationship between the independent variable (independent) with the dependent variable (bound) can be seen in Figure 2, namely:

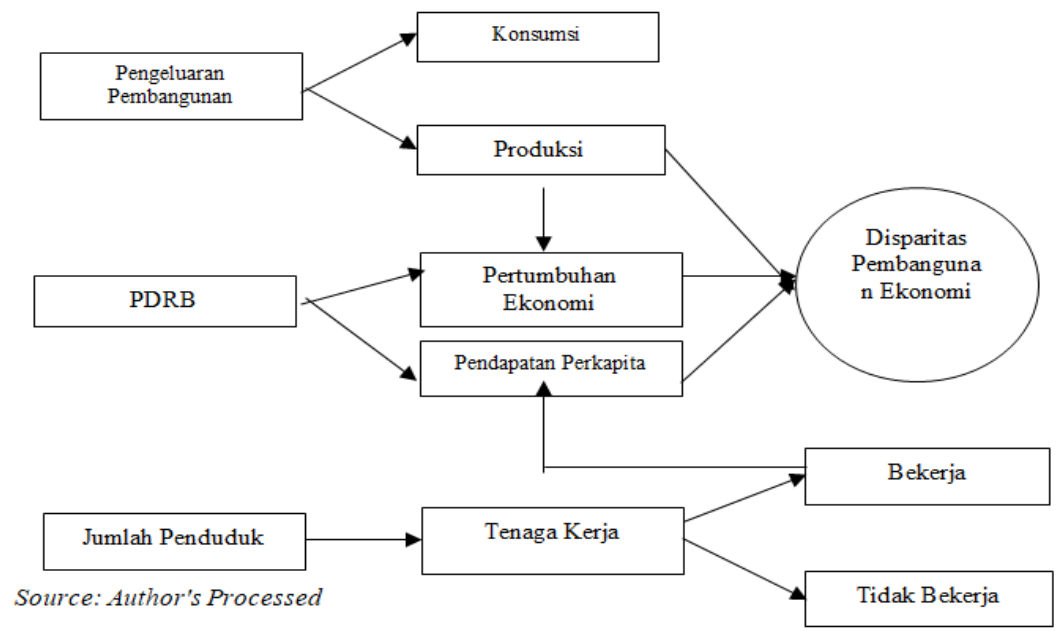

Fig 2. Framework

\section{Research Method}

The research location was carried out in the administrative region of the North Sumatra Provincial Government from 2011 to 2018. The type of data in this research is quantitative data and the source of the data used is secondary data. The source of the data used in this study was sourced from the Central Statistics Agency of North Sumatra Province in several publications. In this study panel data analysis was used to determine the effect of GRDP variable (GRDP), Population Number (POP), Development Expenditure (GE), and labor force variable (AK) on inequality of economic development between Regencies / Cities (VW) in Sumatra Province North. 


\section{Results and Discussion}

\subsection{Development of Gross Regional Domestic Product (PDRB)}

The success of the development of an area or region can be seen from one aspect of the economy, in this case seen from the aspect of the development of the Gross Regional Domestic Product (PDRB) of the region itself. The higher PDRB of a region shows the ability of the region to manage regional finances and shows the regional economic security. PDRB based on constant prices in 2000 North Sumatra province based on BPS data tends to increase. In 2011 the North Sumatra PDRB reached Rp. 87.889 trillion, relatively increased significantly in 2018 amounting to Rp. 134.460 trillion. Figure 3. The following provides an explanation of the increase in PDB at constant 2000 prices from 2011 to 2018.

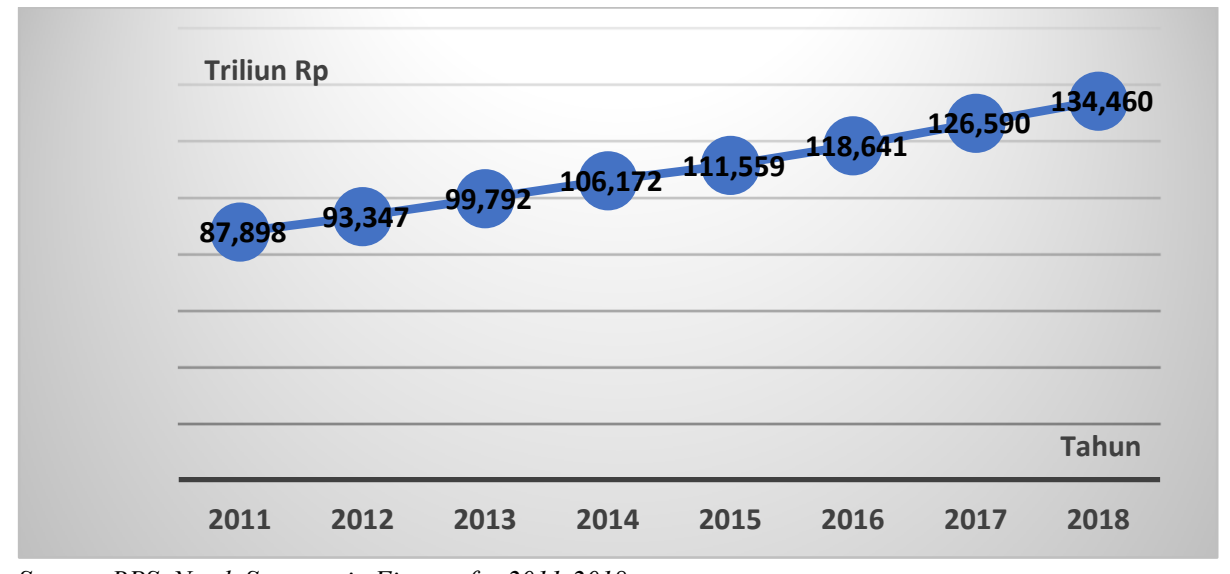

Source: BPS, North Sumatra in Figures for 2011-2018

Fig 3. Increase in PDB from 2011-2018

It can be seen that in 2011 the PDRB based on the highest constant 2000 prices in Medan was Rp. 22,272.42, - billion, while the lowest PDRB in Pakpak Bharat Regency is Rp. 123.12, -. billion. From 2012 to 2018 from the table it appears that the highest PDRB during the period of 8 (eight) years was still dominated by Medan City respectively from 2012 amounting to Rp. $27,234,45$ billion; in 2013 amounting to Rp. 29,352.92, - billion; in 2014 amounting to Rp. 31,334.34 billion; in 2015 amounting to Rp. 33,430.05 billion -; in 2016 amounting to Rp. 35,822.22 billion -; in 2017 amounting to Rp. 38,576.23 billion - and in 2018 Rp. 41,519,32 billion.

Likewise for the lowest PDRB from 2011 to 2018 still in Pakpak Bharat Regency, respectively from 2011 amounting to Rp. 123.12, - billion; in 2012 amounting to Rp. 130.09 billion in 2013 amounting to Rp.137,62 billion; in 2014 amounting to Rp. 145.91 billion -; in 2015 amounting to Rp. 155.42, - billion; in 2016 amounting to Rp. 164.88 billion -; in 2017 amounting to Rp. 174.74 billion and in 2018 Rp. 185.26 billion.

\section{Population (Demographics)}

Suseno states that large population growth does not automatically become capital development. It can even become a burden on other residents. Population growth every year will have an impact on working age that affects the growth and number of the workforce. Employment development is intended to expand productive employment, both in quantity and 
quality. Through employment development, it is expected that an additional absorption of new labor force will occur, reducing the number of unemployed.

Based on BPS data the total population of North Sumatra in 2011 was 12,326,678 people, increasing to $13,215,401$ people in 2018. To see the development of the population from 2011 - 2018 can be seen in.

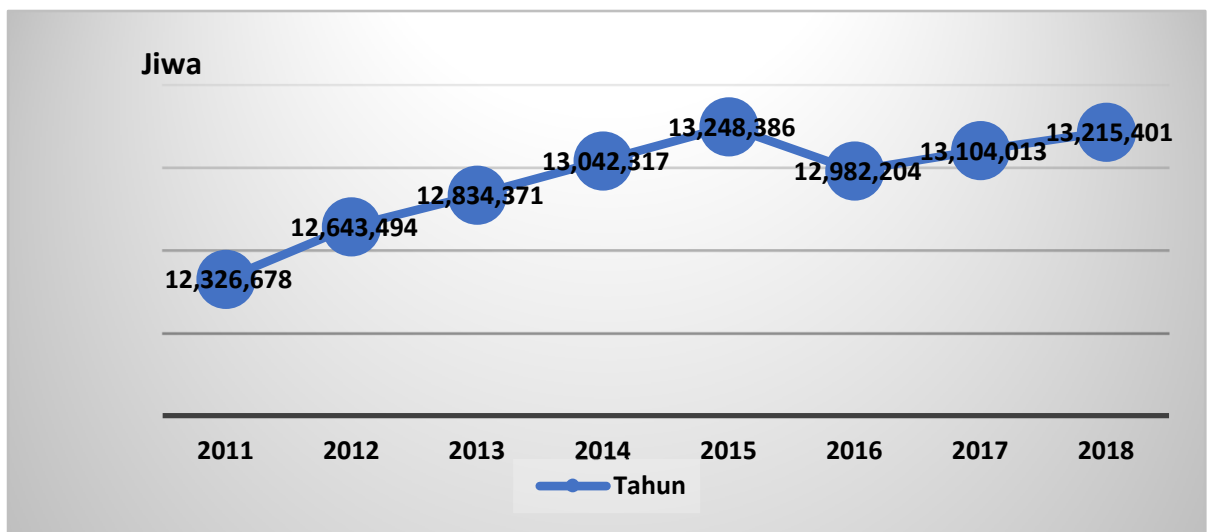

Source: BPS, North Sumatra in Figures for 2011-2018

Fig 4. Development of North Sumatra Population (Year 2011 - 2018)

Figure 4 explains that from 2011 to 2015 the population in North Sumatra continued to increase. In 2016, the number decreased to $12,982,204$ people, this is due to a fundamental difference in the population calculation method. Where in 2016 the data used is the 2016 Population Census data (SP 2016) issued by BPS, while population data other than 2016 are data calculated based on projected figures also released by BPS. It explains that the number of regency / city residents in the province of North Sumatra during 2011 to 2018 continued to increase. The largest population during the study year was the city of Medan where in 2011 there were 2,036,185 inhabitants until 2018 to be 2,122,804 inhabitants. While the lowest population is in the Pakpak Bharat district as many as 34,542 people in 2011 and in 2018 as many as 41,492 people.

\section{Development Expenditures}

Development Expenditures in this study are government expenditures used to finance development in all sectors. The development expenditure used comes from regional government revenues from the tax sector, PAD and other revenues.

Therefore, to ensure the implementation of development in accordance with its objectives, namely the welfare of the community, the government must be more creative and wise in finding and creating new sources of revenue and managing these revenues according to the rules.

Based on the financial statements of each regency / city government in Sumatra province, data on development expenditure for each regency / city is obtained in the following 4.3 table. Table 4.3 explains the amount of development spending of the district / city government of North Sumatra province from 2011 to 2018 continues to increase in all these districts / cities. The biggest development expenditure is the city of Medan where in $2011 \mathrm{Rp}$. 1,135.90 billion increased to Rp. 3,825.13 billion. While the lowest development expenditure 
is the Pakpak Bharat district of Rp. 78.50 billion in 2011 increased in 2018 to Rp. 328.12 billion.

\section{Unemployment Rate}

The unemployment rate in North Sumatra fluctuated from 2011 to 2018 but in general there was a decline. Noted in 2011 the unemployment rate in North Sumatra was 10.98 percent, in 2012 there was an increase to 11.51 percent, in 2013 to 2018 there was a decrease where in 2013 it was 10.10 percent, while in 2014 it was 9, 10 percent, in 2015 amounted to 8.45 percent, in 2016 it was 7.43 percent, and in 2017 it was 6.37 percent and 6.20 percent in 2018.

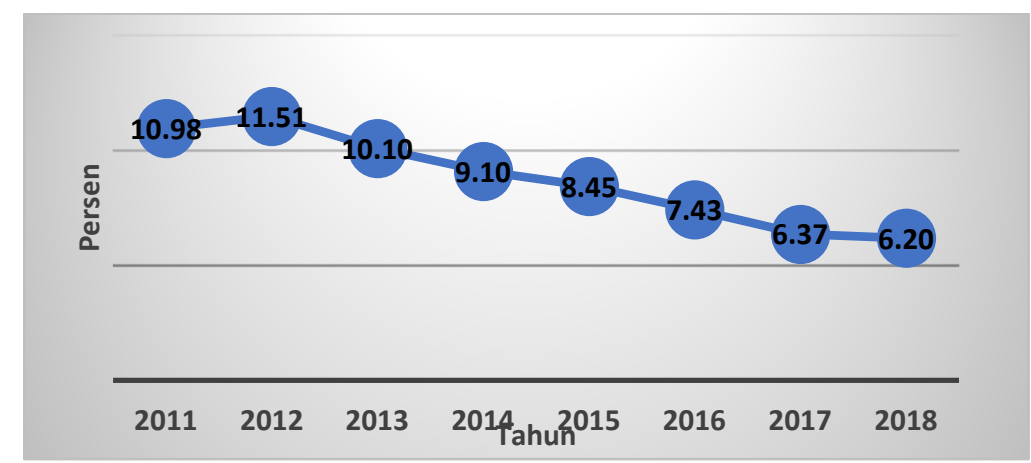

Source: BPS, North Sumatra in Figures for 2011-2018

Fig 5. Development of North Sumatra Unemployment Rate Year $2011-2018$

\section{Model Estimation Results.}

From the results of calculations using the Williamson index method, it can be seen that disparities in the province of North Sumatra during 2011 to 2018 tended to fluctuate. In 2011 the North Sumatra Williamson index of 0.0523 decreased relatively small in 2018 of 0.0503 . The following table 1 presents the Williamson district / city index in the province of North Sumatra during 2011-2018.

Table 1. Williamson Index of Regency / City of North Sumatra

\begin{tabular}{clllllllllll}
\hline No & Kab/ Kota & $\mathbf{2 0 1 1}$ & $\mathbf{2 0 1 2}$ & $\mathbf{2 0 1 3}$ & $\mathbf{2 0 1 4}$ & $\mathbf{2 0 1 5}$ & $\mathbf{2 0 1 6}$ & $\mathbf{2 0 1 7}$ & $\mathbf{2 0 1 8}$ \\
\hline 1 & Nias & 0.0957 & 0.0936 & 0.0918 & 0.0953 & 0.1062 & 0.0578 & 0.0578 & 0.0573 \\
2 & Madina & 0.0811 & 0.0871 & 0.0867 & 0.0830 & 0.0815 & 0.0797 & 0.0799 & 0.0793 \\
3 & Tapsel & 0.0951 & 0.0918 & 0.0945 & 0.0377 & 0.0370 & 0.0371 & 0.0385 & 0.0392 \\
4 & Tapteng & 0.0846 & 0.0879 & 0.0893 & 0.0889 & 0.0897 & 0.0896 & 0.0898 & 0.0905 \\
5 & Taput & 0.0469 & 0.0447 & 0.0470 & 0.0519 & 0.0519 & 0.0539 & 0.0549 & 0.0550 \\
6 & Tobasa & & & & & & & &
\end{tabular}




\begin{tabular}{|c|c|c|c|c|c|c|c|c|c|}
\hline No & Kab/ Kota & 2011 & 2012 & 2013 & 2014 & 2015 & 2016 & 2017 & 2018 \\
\hline & & 0.0222 & 0.0162 & 0.0165 & 0.0119 & 0.0132 & 0.0134 & 0.0114 & 0.0115 \\
\hline 7 & $\begin{array}{l}\text { Labuhan } \\
\text { Batu }\end{array}$ & 0.0092 & 0.0037 & 0.0017 & 0.0025 & 0.0221 & 0.0251 & 0.0265 & 0.0275 \\
\hline 8 & Asahan & 0.1167 & 0.1130 & 0.0257 & 0.0247 & 0.0249 & 0.0266 & 0.0291 & 0.0296 \\
\hline 9 & Simalungun & 0.0667 & 0.0677 & 0.0686 & 0.0673 & 0.0649 & 0.0639 & 0.0654 & 0.0653 \\
\hline 10 & Dairi & 0.0179 & 0.0200 & 0.0208 & 0.0247 & 0.0239 & 0.0244 & 0.0260 & 0.0261 \\
\hline 11 & Karo & 0.0246 & 0.0130 & 0.0083 & 0.0111 & 0.0100 & 0.0082 & 0.0068 & 0.0075 \\
\hline 12 & $\begin{array}{l}\text { Deli } \\
\text { Serdang }\end{array}$ & 0.0062 & 0.0139 & 0.0234 & 0.0304 & 0.0350 & 0.0419 & 0.0440 & 0.0489 \\
\hline 13 & Langkat & 0.0485 & 0.0604 & 0.0641 & 0.0540 & 0.0524 & 0.0504 & 0.0523 & 0.0515 \\
\hline 14 & $\begin{array}{l}\text { Nias } \\
\text { Selatan }\end{array}$ & 0.0785 & 0.0703 & 0.0705 & 0.0755 & 0.0756 & 0.0799 & 0.0814 & 0.0813 \\
\hline 15 & $\begin{array}{l}\text { Humbang } \\
\text { Has }\end{array}$ & 0.0334 & 0.0312 & 0.0311 & 0.0384 & 0.0384 & 0.0412 & 0.0417 & 0.0419 \\
\hline 16 & $\begin{array}{l}\text { Pakpak } \\
\text { Barat }\end{array}$ & 0.0265 & 0.0259 & 0.0298 & 0.0309 & 0.0314 & 0.0310 & 0.0311 & 0.0314 \\
\hline 17 & Samosir & 0.0106 & 0.0101 & 0.0111 & 0.0058 & 0.0041 & 0.0031 & 0.0037 & 0.0037 \\
\hline 18 & Sergei & 0.0424 & 0.0431 & 0.0455 & 0.0407 & 0.0373 & 0.0347 & 0.0359 & 0.0360 \\
\hline 19 & Sibolga & 0.0095 & 0.0110 & 0.0119 & 0.0055 & 0.0041 & 0.0033 & 0.0129 & 0.0050 \\
\hline 20 & $\begin{array}{l}\text { Tanjung } \\
\text { Balai }\end{array}$ & 0.0053 & 0.0026 & 0.0013 & 0.0016 & 0.0005 & 0.0011 & 0.0030 & 0.0042 \\
\hline 21 & $\begin{array}{l}\text { Pematang } \\
\text { Siantar }\end{array}$ & 0.0076 & 0.0073 & 0.0082 & 0.0082 & 0.0069 & 0.0066 & 0.0074 & 0.0070 \\
\hline 22 & $\begin{array}{l}\text { Tebing } \\
\text { Tinggi }\end{array}$ & 0.0099 & 0.0098 & 0.0101 & 0.0130 & 0.0123 & 0.0129 & 0.0129 & 0.0124 \\
\hline 23 & Medan & 0.3010 & 0.3172 & 0.3272 & 0.3265 & 0.3389 & 0.3492 & 0.3562 & 0.3733 \\
\hline 24 & Binjai & 0.0135 & 0.0146 & 0.0162 & 0.0148 & 0.0138 & 0.0140 & 0.0145 & 0.0142 \\
\hline 25 & $\begin{array}{l}\text { Padang } \\
\text { Sidimpuan }\end{array}$ & 0.0533 & 0.0537 & 0.0544 & 0.0049 & 0.0541 & 0.0565 & 0.0570 & 0.0588 \\
\hline
\end{tabular}

Source: Self-processed

Estimation using the fixed effect method is based on the chow test results and the haussman test results, where the chow test results are shown in table 2 the following: 
Table 2. Chow Test Results

Redundant Fixed Effects Tests

Pool: Untitled

Test cross-section fixed effects

\begin{tabular}{lccr}
\hline Effects Test & Statistic & d.f. & Prob. \\
\hline Cross-section F & 503.940360 & $(24,146)$ & 0.0000 \\
\hline
\end{tabular}

Determination of the use between the common effect and fixed effect methods using the chow test, where if the probability is $>0.10,0.05,0.01$ then the common effect method is better used. Conversely, if the probability $<0.10,0.05,0.01$, then the use of the fixed effect method is better used.

From the estimation results with the chow test obtained probability $<0.10,0.05,0.01$ so that the fixed effect method is better to use.

The next step is conducting a Haussman test to determine whether the fixed effect or random effect method is better used. Haussman test results can be seen in the table 3 follows:

Table 3. Haussman Test Results

Correlated Random Effects - Haussman Test

Pool: Untitled

Test cross-section random effects

\begin{tabular}{lccr}
\hline \hline Test Summary & Chi-Sq. Statistic & Chi-Sq. d.f. & Prob. \\
\hline \hline Cross-section random & 37.562195 & 4 & 0.0000 \\
\hline \hline
\end{tabular}

Determination of the use between the fixed effect and random effect methods using the Haussman test, where if the probability is $>0.10,0.05,0.01$ then the random effect method is better used. Conversely, if the probability $<0.10,0.05,0.01$, then the use of the fixed effect method is better used.

From the estimation results with the haussman test obtained probability $<0.10,0.05,0.01$ so that the fixed effect method is better to use. 
Table 4. Estimation Results of Fixed Effect Method

Dependent Variable: LOG(VW?)

Method: Pooled EGLS (Cross-section weights); Sample: 20112018

\begin{tabular}{|c|c|c|c|c|}
\hline Variable & Coefficient & Std. Error & t-Statistic & Prob. \\
\hline $\mathrm{C}$ & -9.782287 & 1.919361 & -5.096637 & 0.0000 \\
\hline LOG(PDRB?) & -0.177096 & 0.050583 & -3.501086 & 0.0006 \\
\hline LOG(POP?) & 0.573420 & 0.140704 & 4.075369 & 0.0001 \\
\hline LOG(GE?) & 0.036701 & 0.019571 & 1.875256 & 0.0628 \\
\hline LOG(TPT?) & 0.014832 & 0.016386 & 0.905152 & 0.3669 \\
\hline \multicolumn{5}{|l|}{ Fixed Effects (Cross) } \\
\hline NIAS-C & 1.028671 & & & \\
\hline MADINA-C & 0.947268 & & & \\
\hline - TAPSEL-C & 0.553278 & & & \\
\hline TAPTENG $-\mathrm{C}$ & 1.103665 & & & \\
\hline TAPUT $-\mathrm{C}$ & 0.687944 & & & \\
\hline- TOBASA $-\mathrm{C}$ & -0.384188 & & & \\
\hline LBATU-C & -1.292764 & & & \\
\hline _ASAHAN-C & -0.107045 & & & \\
\hline _SIMALUNGUN--C & 0.483473 & & & \\
\hline DAIRI--C & -0.057431 & & & \\
\hline KARO--C & -1.074170 & & & \\
\hline DSERDANG--C & -0.527060 & & & \\
\hline LAANGKAT--C & 0.231886 & & & \\
\hline NISEL--C & 1.031321 & & & \\
\hline HUMBAHAS--C & 0.602904 & & & \\
\hline _PAKPAKB--C & 0.876519 & & & \\
\hline SAMOSIR--C & -1.205839 & & & \\
\hline _SERGAI--C & 0.111041 & & & \\
\hline _SIBOLGA--C & -0.857669 & & & \\
\hline TBALAI--C & -2.453909 & & & \\
\hline -PSIANTAR--C & -1.148807 & & & \\
\hline -TTINGGI--C & -0.466664 & & & \\
\hline _MEDAN--C & 1.881713 & & & \\
\hline _BINJAI--C & -0.492470 & & & \\
\hline _PSIDEMPUAN--C & 0.528333 & & & \\
\hline \multicolumn{5}{|c|}{ Effects Specification } \\
\hline \multicolumn{5}{|c|}{ Weighted Statistics } \\
\hline R-squared & 0.994995 & Mean dependent var & & -15.30609 \\
\hline Adjusted R-squared & 0.994035 & S.D. dependent var & & 16.64737 \\
\hline S.E. of regression & 0.389273 & Sum squared resid & & 22.12385 \\
\hline F-statistic & 1036.513 & Durbin-Watson stat & & 1.221867 \\
\hline Prob(F-statistic) & 0.000000 & & & \\
\hline
\end{tabular}

Source: Regression results, processed by yourself 
Regression results for the independent variables produce the coefficient of determination (R2) as follows: R2PDRB (POP, GE, TPT) equals 0.988; R2POP (PDRBP, GE, TPT) equals 0.984; R2GE (PDRB, POP, TPT) equals 0.857; R2TPT (GRDP, POP, GE) is equal to 0.705 (Table 4.9). Compared with R2VW (PDRBP, POP, GE, TPT) of 0.994, the coefficient of determination of PDRBP, POP, GE and TPT independent variables is smaller than that. This means that the model used is good and can be analyzed.

\begin{abstract}
Analysis of Estimation Results for Variables Affecting Economic Development Disparity in North Sumatra.

Estimation experiments are conducted on variables that are considered to influence income disparity, such as PDRB, population, development spending and unemployment rate. Significant estimation results are given PDRB variable, population and development expenditure.

Estimation results in all districts / cities in North Sumatra province based on the amount of income disparity intercept (VW) results of the above estimation can also be seen that the average increase in regional income disparity is constant without being influenced by other factors is the largest compared to income disparity the other region (VW) is Tanjung Balai City, which is -2.453909 . While the increase in regional income disparity (VW) in the second place is Medan's income disparity (VW), which amounted to 1.881713 . In the third place the increase in regional income disparity (VW) is Labuhan Batu district, which is equal to 1.292764. The lowest increase in regional income disparity (VW) was in Dairi Regency by 0.057431 followed by Asahan Regency by -0.107045 and Serdang Bedagai District by 0.111041 .
\end{abstract}

\title{
PDRB
}

The PDRB regression coefficient is equal to -0.177096 . This means that if the PDRB increases by 100 percent, the income disparity (VW) will decrease by 17.71 percent. Conversely, if the PDRB falls by 100 percent, the income disparity will increase by 17.71 percent. The effect of this PDRB variable is relatively low and significant at a 90 percent confidence level. This shows that the PDRB has a negative and significant effect on income disparity in North Sumatra.

This proves that the estimation results of this study are in accordance with the research hypothesis.

\section{Total population}

The POP variable regression coefficient is 0.573420 which means that if POP increases 100 percent it will increase economic development (VW) disparity by 57.34 percent. The influence of POP on VW is relatively the highest of other independent variables and has a positive and significant effect on the 90 percent confidence level of economic development disparity in North Sumatra.

\section{Development Expenditures}

Estimation results show the GE variable regression coefficient of 0.036701 . It means that each increase of GE by 100 percent, the disparity in economic development (VW) will increase by 3.67 percent. The influence of GE variables on VW is positive and significant at the 95 percent confidence level.

Unemployment Rate

Estimation results show the coefficient of TPT variable of 0.014832 . This means that every 100 percent increase in unemployment will increase disparity in economic development 
by 1.48 percent. The effect of TPT variable on VW was not significant at the 90 percent confidence level. But the direction is positive and is in accordance with the hypothesis of this study.

\section{Model Suitability Test Results Concurrent test results (F-statistics)}

The F-count value is equal to 1036,513 with the F-statistic probability of 0.00000 that means that simultaneously (independent) independent variables (PDRBP, POP, GE, and TPT) affect the dependent variable (VW). Estimation results have met the suitability of the model for concurrent test, so the estimation results can be used for analysis.

\section{Results coefficient of determination (R2)}

$\mathrm{R} 2$ lies between 0 and 1 . R2 equals 1 . It means that the independent variables explain 100 percent of the variation of the dependent variable. Conversely, R2 equals 0 , meaning that the independent variables in the model do not explain the slightest variation in the dependent variable. The model is said to be better if R2 gets closer to 1 (Gujarati: 99). The estimated model yields R2 of 0.9949. The presence of independent variables (PDRBP, POP, GE and TPT) are able to explain the dependent variable (VW) by 99.49 percent, the remaining 0.51 percent is explained by other variables outside the model. With R2 0.9949, the estimation results meet the suitability test from the aspect of the coefficient of determination. Estimation results are worth analyzing.

\section{Partial Test Result (t-test)}

A partial test is also called a test of significance. PDRBP t-value is equal to -3.501086 with a probability of 0.0006 smaller than $\alpha=0.05$ which means that the PDRB variable significantly affects VW negatively, the t-statistic POP value is equal to 4.075369 with a probability of 0,0001 smaller $\alpha=0.05$ which means that the POP variable significantly affects VW positively, the GE variable with a t-statistic value of 1.875256 with a probability of 0.0628 smaller $\alpha=0.05$ which means that the GE variable significantly affects VW significantly positive. While the TPT variable t-statistic value of 0.905152 with a probability of 0.3669 is greater than $\alpha=0.05$ which means that the TPT variable does not significantly affect VW. So, the estimation results of the model have met the suitability test from the aspect of partial test. The estimation results of the model can be analyzed.

\section{Classic Deviation Test Results}

Ragnar Frisch states that a regression model is affected by Multicollinearity if there is a perfect linear relationship between some or all independent variables of a regression model. How to detect Multicollinearity problems can be done in 2 (two) ways, namely:

1. Correlation between variables

2. Using partial correlation

In this study the Multicollinearity test uses the partial correlation method, the results of the partial correlation test can be seen in Appendix 7. The results of the test can be displayed as follows: 
Table 5. Coefficient of Determination among Independent Variables

\begin{tabular}{|c|c|c|c|}
\hline $\begin{array}{l}\text { Dependent } \\
\text { Variabel } \\
\end{array}$ & Independent Variabel & $\mathbf{R}^{2}$ & Keterangan \\
\hline PDRBP & POP, GE, TPT & 0,988 & $\begin{array}{l}\text { Trouble-free } \\
\text { Multicollinearity }\end{array}$ \\
\hline POP & PDRBP, GE, TPT & 0,984 & $\begin{array}{l}\text { Trouble-free } \\
\text { Multicollinearity }\end{array}$ \\
\hline GE & PDRBP, POP, TPT & 0,857 & $\begin{array}{l}\text { Trouble-free } \\
\text { Multicollinearity }\end{array}$ \\
\hline TPT & PDRBP, POP, GE & 0,705 & $\begin{array}{l}\text { Trouble-free } \\
\text { Multicollinearity }\end{array}$ \\
\hline
\end{tabular}

Source: Regression results, processed by yourself

Regression results for the independent variables produce the coefficient of determination (R2) as follows: R2PDRB (POP, GE, TPT) equals 0.988; R2POP (PDRBP, GE, TPT) equals 0.984; R2GE (PDRB, POP, TPT) equals 0.857; R2TPT (PDRB, POP, GE) is equal to 0.705 (Table 4.9). Compared with R2VW (PDRBP, POP, GE, TPT) of 0.994, the coefficient of determination of PDRBP, POP, GE and TPT independent variables is smaller than that. This means that the model used is good and can be analyzed.

\section{Conclusions and Suggestions}

\section{Conclusion}

1) The coefficient of determination on the estimated results of economic development disparity in North Sumatra can be explained by the GRDP variables, population, expenditure and unemployment rate with the model used.

2) The variables used to explain the disparity of economic development variables indicate the direction of influence in accordance with the hypothesis. GRDP has a negative and significant effect. The number of population influences and development spending has a positive and significant effect on the disparity in economic development while the unemployment rate has no significant effect on economic development in North Sumatra.

3) Patient coefficient variables are variables that explain the economic development disparity variable, the largest is the population number variable, followed successively by the GRDP variable, Development expenditure, and unemployment rate.

\section{Suggestion}

1) To reduce inequality or disparity in economic development, the government should continue to improve economic performance by looking for new sources of revenue and budget efficiency that can be utilized for development in each sector.

2) The government should open more new jobs by making it easier for investors to invest in the region by issuing regulations and policies that encourage the growth of these investments. With the growth of investment in the region will absorb a lot of labor that in turn will reduce unemployment.

3) It is better for the government to socialize more about the importance of family planning in regulating birth rates by providing cheap and free contraception to 
new partners, providing counseling and making health facilities comfortable and easily accessible to the community.

4. There should be more research on inequality with broader and more complex coverage and methods as well as with a variety of supporting variables so that they will add and enrich the treasury of knowledge.

\section{References}

[1] Mankiw, N. Gregory, "Teori Makroekonomi", Edisi Keempat, Penerbit Erlangga, (2000).

[2] Bonar dan Susilowati, "Dampak Berbagai Kebijakan Ekonomi di Sector Agroindustri Terhadap Distribusi Pendapatan Sektoral, Tenaga Kerja dan Rumahtangga", Tesis, (2008).

[3] Akita, Takahiro, Armida S Alisjahbana, "Regional Income Inequality in Indonesia and The Initial Impact of The Economic Crisis", Bulletin of Indonesia Econmic Studies, Vol. 38, No.2, (2002).

[4] Alkadri, "Sumber-sumber Pertumbuhan Ekonomi Indonesia Selama 1969-1996", Jurnal Ekonomi, BPPT, Volume 9.2, (2004).

[5] Arsyad, Lincolin, "Ekonomi Pembangunan", Edisi 4, Yogyakarta, Penerbit Aditya Media, (2004).

[6] Ardito Bhinadi, "Sumber-Sumber Pertumbuhan Ekonomi dan Disparitas Regional di Indonesia", Tesis program Studi Magister Sains Universitas Gajah Mada, Yogyakarta, (2004).

[7] BPS Provinsi Sumatera Utara, 2006 - 2013, "Sumatera Utara Dalam Angka" Berbagai Edisi, Medan.

[8] Barro, J, "Inequality and Growth in a Panel of Countries", Journal of Economic Growth, Vol 5, No.1, (2006).

[9] Bonet, J, "Fiscal Decentralization and Regional Income Disparities Evidence From the Colombian Experience", The Annuals of Regional Science 40, (2006)

[10]Budiantoro, Hartono, "Analisis Ketimpangan Pembangunan Ekonomi di Provinsi Jawa Tengah”, Tesis, Undip, Semarang, (2008).

[11]Engelbrecht Hans-Jurgen, "Human Capital and Economic Growth Cross-Section evidence OECD Countries", Jurnal Economic Record, East Ivanhoe, Vol. 79, (2003)

[12] Imam Ghozali, "Aplikasi Analisis Multivariat dengan Program SPSS", Universitas Diponegoro. Semarang, (2001).

[13] Insukindro, Makhfatih Akhmad, Maryatmo, "Dasar-Dasar Ekonometrika”, Program Studi MEP UGM, Jogyakarta, (2000).

[14] Irwan dan Suparmoko, "Ekonomi Pembangunan", Liberty, Yogyakarta, (1987)

[15] Ivancevich John M, Hoon Lee Soo, "Human Resource Management in Asia", McGraw Hill, (2002).

[16] Jhingan, M.L, "Ekonomi Pembangunan dan Perencanaan", Terjemahan oleh D. Guritno, Edisi ke-1, Cetakan ke-10, PT. Raja Grafindo Persada, Jakarta, (2004)

[17]Lincolin Arsyad, Pengantar Perencanaan dan Pembangunan Ekonomi Daerah", Edisi Pertama, BPFE, Yogyakarta, (2004).

[18] Mankiw, N. Gregory, "Macroeconomics", Fourth Edition, Worth Publisher, Inc, New York, (2003). 